\title{
Carbon liberated from CO-releasing molecules attenuates leukocyte infiltration in the small intestine of thermally injured mice
}

\author{
Bing-Wei Sun, Qin Jin, Yan Sun, Zhi-Wei Sun, Xi Chen, Zhao-Yong Chen, Gediminas Cepinskas
}

Bing-Wei Sun, Qin Jin, Yan Sun, Zhi-Wei Sun, Xi Chen, ZhaoYong Chen, Department of Burns and Plastic Surgery, Affiliated Hospital, Jiangsu University, Zhenjiang 212001, Jiangsu Province, China

Gediminas Cepinskas, Centre for Critical Illness Research, Lawson Health Research Institute, 800 Commissioners Rd. E., London, Ontario, N6A 4G4, Canada

Correspondence to: Dr. Bing-Wei Sun, Department of Burns and Plastic Surgery, Affiliated Hospital, Jiangsu University, 438 Jiefang Rd, Zhenjiang 212001, Jiangsu Province,

China. sunbinwe@hotmail.com

Telephone: +86-511-85026183 Fax: +86-511-5029089

Received: July 12, $2007 \quad$ Revised: September 8, 2007

\begin{abstract}
AIM: To determine whether Carbon (CO) liberated from CO-releasing molecules attenuates leukocyte infiltration in the small intestine of thermally injured mice.
\end{abstract}

METHODS: Thirty-six mice were assigned to four groups. Mice in the sham group $(n=9)$ were underwent to sham thermal injury; mice in the burn group $(n=9)$ received $15 \%$ total body surface area full-thickness thermal injury; mice in the burn + CORM-2 group $(n=9)$ were underwent to the same thermal injury with immediate administration of tricarbonyldichlororut henium (II) dimer CORM-2 (8 mg/kg, i.v.); and mice in the burn+DMSO group $(n=9)$ were underwent to the same thermal injury with immediate administration of $160 \mu \mathrm{L}$ bolus injection of $0.5 \%$ DMSO/saline. Histological alterations and granulocyte infiltration of the small intestine were assessed. Polymorphonuclear neutrophil (PMN) accumulation (myeloperoxidase assay) was assessed in mice mid-ileum. Activation of nuclear factor (NF)- $\kappa B$, expression levels of intercellular adhesion molecule-1 (ICAM-1) and inducible heme oxygenase in mid-ileum were assessed.

RESULTS: Treatment of thermally injured mice with CORM-2 attenuated PMN accumulation and prevented activation of NF- $\mathrm{KB}$ in the small intestine. This was accompanied by a decrease in the expression of ICAM-1. In parallel, burn-induced granulocyte infiltration in midileum was markedly decreased in the burn mice treated with CORM-2.

CONCLUSION: CORM-released CO attenuates leukocyte infiltration in the small intestine of thermally injured mice by interfering with $\mathrm{NF}-\kappa \mathrm{B}$ activation and protein expression of ICAM-1, and therefore suppressing the pro-adhesive phenotype of endothelial cells.

(c) 2007 WJG. All rights reserved.

Key words: Leukocyte infiltration; Carbon monoxide; Thermal injury; Small intestine

Sun BW, Jin Q, Sun Y, Sun ZW, Chen X, Chen ZY, Cepinskas G. CO liberated from CO-releasing molecules attenuates leukocyte infiltration in the small intestine of thermally injured mice. World J Gastroenterol 2007; 13(46): 6183-6190

http://www.wjgnet.com/1007-9327/13/6183.asp

\section{INTRODUCTION}

Systemic inflammatory response syndrome (SIRS) and multiple organ failure (MOF) still continue to be leading causes of morbidity and mortality in severe burn patients ${ }^{[1,2]}$. The intestine is considered to be the critical organ in the development of organ dysfunction in trauma, burns, and intensive care unit patients ${ }^{[3]}$. Thermal injury is accompanied by complex events that exert deleterious effects on various organs, such as the small intestine, distant from the original burn wound. Following thermal injury, the small intestine is subjected to ischemia, and consequently, especially during burn resuscitation, reperfusion injury occurs ${ }^{[4]}$. Intestinal ischemia-reperfusion results in organ injury through both tissue hypoxia and reperfusion phenomena mediated by neutrophils ${ }^{[5,6]}$. A variety of cytokines are released into the microcirculation by neutrophils, endothelial cells and monocytes during phases of hypoxia and reperfusion ${ }^{[7,8]}$. Although the pathophysiological basis of organ damage remains unclear, there is increasing evidence that leukocyte infiltration into intestinal tissue plays an important role in bacterial or endotoxin translocation and development of SIRS after thermal injury ${ }^{[0-12]}$.

A lot of evidence indicates that endogenous Carbon (CO), a by-product of inducible heme oxygenase (HO-1), modulates inflammation. In addition, some experiments have determined that the administration of exogenous CO inhibits lipopolysaccharide (LPS)-induced production 
of cytokines both in vivo and in vitro, and consequently exhibits an important cytoprotective function and antiinflammatory properties that are beneficial for the resolution of acute inflammation ${ }^{[13-15]}$.

Recently, transitional metal carbonyls have been identified as potential CO-releasing molecules (CORMs), with the potential to facilitate the pharmaceutical use of $\mathrm{CO}$ by delivering it to tissues and organs ${ }^{[16]}$. CORMs have been shown to act pharmacologically in rat aorta and cardiac tissue in which liberation of $\mathrm{CO}$ induced vasorelaxant effects ${ }^{[17-20]}$ and decreased myocardial ischemia-reperfusion injury ${ }^{[21,22]}$, respectively. Our previous studies ${ }^{[23,24]}$ have shown that burn-induced overexpression of adhesion molecules [such as intercellular adhesion molecule-1 (ICAM-1) and vascular cell adhesion molecule-1] on endothelial cells and leukocytes may contribute to liver and lung tissue injury, subsequently leading to multiple organ dysfunction syndrome (MODS). We also confirmed that CORM-released CO attenuated leukocyte sequestration in the liver and lungs of burned mice by interfering with NF$\kappa \mathrm{B}$ activation and protein expression of ICAM-1, therefore suppressing the pro-adhesive phenotype of endothelial cells. However, it is still unknown if CORM-released CO can exert its anti-inflammatory and protective effects in the small intestine. Based on these preliminary observations, in this study we employed tricarbonyldichlororuthenium (II) dimer (CORM-2), one of the novel group of CORMs, to determine whether it attenuated leukocyte infiltration to the intestinal tissue of thermally injured mice.

\section{MATERIALS AND METHODS}

\section{Materials}

CORM-2 was obtained from Sigma-Aldrich and was solubilized in DMSO to obtain a $10 \mathrm{mmol} / \mathrm{L}$ stock solution. Polyclonal or monoclonal antibodies against ICAM-1 and HO-1 were purchased from Santa Cruz Biotechnology. All other chemicals were reagent grade and obtained from Sigma unless otherwise stated.

\section{Animals and burn protocol}

C57BL/ 6 mice (36 male; body weight $20 \pm 2 \mathrm{~g}$ ) were fed a standard laboratory diet and water ad libitum. Mice were assigned to four groups. Mice in the sham group $(n=$ 9) were underwent to sham thermal injury; mice in the burn group $(n=9)$ received $15 \%$ total body surface area (TBSA) full-thickness thermal injury; mice in the burn + DMSO group $(n=9)$ were underwent to the same thermal injury with immediate administration of $160 \mu \mathrm{L}$ bolus injection of $0.5 \% \mathrm{DMSO} /$ saline; and mice in the burn + CORM-2 group $(n=9)$ were underwent to the same thermal injury with immediate administration of CORM-2 $(8 \mathrm{mg} / \mathrm{kg}$, i.v.). The experimental protocol was approved by The Council on Animal Care at Jiangsu University for the protection and welfare of animals. Under anesthesia with spontaneous inhalation of isoflurane $/ \mathrm{N}_{2} \mathrm{O}$ (Abbott Laboratories, Mississauga, ON, Canada) in a $60 \%$ oxygen $/ 40 \%$ nitrogen mixture, the dorsum of each mouse was shaved and the animal was subjected to $15 \%$ TBSA full-thickness thermal injury as previously described ${ }^{[25,26]}$.
Table 1 Histological scoring system for ileum and jejunum sections stained with hematoxylin/eosin

\begin{tabular}{lccccccc}
\hline & \multicolumn{2}{c}{ Granulocyte infiltration } & & \multicolumn{3}{c}{ Hydropic degeneration } \\
\cline { 2 - 4 } \cline { 6 - 8 } & $\mathbf{0}$ & $\mathbf{1}$ & $\mathbf{2}$ & & $\mathbf{0}$ & $\mathbf{1}$ & $\mathbf{2}$ \\
\hline Ileum & No & Moderate & Intense & & No & Moderate & Intense \\
Jejunum & No & Moderate & Intense & & No & Moderate & Intense \\
\hline
\end{tabular}

Sham animals were immersed in a water bath at room temperature. All animals were resuscitated with $1.5 \mathrm{~mL}$ saline immediately after thermal (or sham) injury. No wound care was required for the burn wounds. This burn method achieves a histologically proven, full-thickness scald injury ${ }^{[27,28]}$. The animals were sacrificed at $24 \mathrm{~h}$ after experimental manipulation.

\section{Ileum histologic studies}

The mid-ileum specimens harvested from different groups of animals were immersed in $4 \%$ formaldehyde solution at $24 \mathrm{~h}$ after thermal injury. The tissue was embedded in paraffin wax, serially sectioned, and stained with hematoxylin-eosin. Ileal morphologic characteristics were evaluated by light microscopy. Ileum tissue was evaluated for density of granulocytes and degree of hydropic degeneration. Tissues were evaluated in a semi-quantitative manner by two experienced independent examiners that were blinded to the experimental groups (Table 1). A scoring system was used for each item using 0 up to 2 points for the different states of organ damage (with 2 being most granulocytes, edema and degeneration; Table 1). Afterwards, the mean \pm SEM of each item was calculated.

\section{Preparation of intestinal homogenates}

Immediately after withdrawing blood, the intestine was exposed. Leaving approximately the first $5-\mathrm{cm}$ long proximal segment of the intestine, 3 - $\mathrm{cm}$-long segments of jejunum and ileum were removed, cleaned, and snap-frozen in liquid nitrogen. The samples were stored at $-70^{\circ} \mathrm{C}$. Equal weights $(100 \mathrm{mg}$ wet weight) of intestine from various groups were suspended in $1 \mathrm{~mL}$ PBS and sonicated (30 cycles, twice, for $30 \mathrm{~s}$ ) on ice ${ }^{[29]}$. Homogenates were cleared by centrifuging at $12000 \mathrm{r} / \mathrm{min}$ at $4^{\circ} \mathrm{C}$, and the supernatants were stored at $-70^{\circ} \mathrm{C}$. Protein levels in the homogenates were determined using the BioRad (Hercules, CA, USA) assay kit.

\section{Myeloperoxidase (MPO) activity}

MPO activity was measured in ileum tissue using a procedure similar to that documented by Hillegas et a $t^{30,311}$. Tissue samples were homogenized in $50 \mathrm{mmol} / \mathrm{L}$ potassium phosphate buffer (PB) (pH 6.0), and centrifuged at 10000 $\times g(10 \mathrm{~min})$; pellets were suspended in $50 \mathrm{mmol} / \mathrm{L}$ $\mathrm{PB}$ containing $0.5 \%$ hexadecyltrimethylammonium bromide. After sonication, the samples were centrifuged at $10000 \times g$ for $10 \mathrm{~min}$. Aliquots $(0.3 \mathrm{~mL})$ were added to $2.3 \mathrm{~mL}$ of reaction mixture containing $50 \mathrm{mmol} / \mathrm{L} \mathrm{PB}$, $o$-dianisidine, and $20 \mathrm{mmol} / \mathrm{L} \mathrm{H}_{2} \mathrm{O}_{2}$ solution. One unit of enzyme activity was defined as the amount of MPO 
Table 2 Histological scoring (score in Table 1) of ileum and jejunum tissue stained with hematoxylin/eosin $24 \mathrm{~h}$ after thermal injury

\begin{tabular}{|c|c|c|c|c|c|c|}
\hline & \multicolumn{3}{|c|}{ Granulocyte infiltration } & \multicolumn{3}{|c|}{ Hydropic degeneration } \\
\hline & Sham & Burn & Burn + CORM & Sham & Burn $\mathrm{B}$ & Burn + CORM \\
\hline Ileum & $0.60 \pm 0.1$ & $1.92 \pm 0.4^{\mathrm{a}}$ & $0.88 \pm 0.2^{c}$ & 0 & $1.8 \pm 0.2$ & $1.7 \pm 0.1$ \\
\hline Jejunum & $0.54 \pm 0.1$ & $1.5 \pm 0.2^{\mathrm{a}}$ & $0.64 \pm 0.2^{c}$ & 0 & $1.6 \pm 0.1$ & $1.6 \pm 0.2$ \\
\hline
\end{tabular}

0 , no injury; 1 , moderate injury; 2 , severe injury. Values are presented as mean \pm SEM. ${ }^{a} P<0.05$ vs sham group; ${ }^{c} P<0.05$ vs burn group.

present that caused a change in absorbance measured at $460 \mathrm{~nm}$ for $3 \mathrm{~min}$. MPO activity was expressed as $\mathrm{U} / \mathrm{g}$ tissue.

\section{Measurement of ICAM-1}

ICAM-1 levels in ileum tissue homogenates were measured using enzyme-linked immunosorbent assay (ELISA) kits (R\&D Systems, Minneapolis, MN, USA) following the manufacturer's instructions.

\section{Western blot analysis}

Tissues were homogenized for extraction in icecold mild lysis buffer, containing 1\% Nonidet P-40, $0.15 \mathrm{~mol} / \mathrm{L} \mathrm{NaCl}, 0.01 \mathrm{~mol} / \mathrm{L}$ sodium phosphate $(\mathrm{pH} 7.2)$, $2 \mathrm{mmol} / \mathrm{L}$ EDTA, $50 \mathrm{mmol} / \mathrm{L}$ sodium fluoride, $0.2 \mathrm{mmol} / \mathrm{L}$ sodium vanadate, and $1 \mu \mathrm{g} / \mathrm{mL}$ aprotinin. The tissue homogenates were centrifuged at $20000 \times g$ for $15 \mathrm{~min}$ and supernatants were collected. SDS-PAGE was performed on equivalent amounts of protein samples using precast $7 \%$ resolving $/ 4 \%$ stacking Tris $/ \mathrm{HCl}$ gels (Bio-Rad, Hercules, CA, USA). Separated proteins were then transferred to PVDF membranes (Amersham Pharmacia Biotech, Piscataway, NJ, USA). Membranes were blocked in 5\% non-fat milk in TBS buffer containing $0.1 \%$ Tween 20 (TBST) for $1 \mathrm{~h}$ at room temperature. Blocked membranes were incubated with primary antibodies specific for mouse ICAM-1 and HO-1 at a concentration of 1:1000 and 1:5000, respectively, in TBST overnight at $4^{\circ} \mathrm{C}$. Then, the membranes were washed and probed with horseradish-peroxidase-conjugated secondary antibody (Amersham Pharmacia Biotech, Piscataway, NJ, USA) for $1 \mathrm{~h}$ at room temperature. Chemiluminescence detection was performed with the Amersham enhanced chemiluminescence detection kit according to the manufacturer's instructions. To ensure a similar amount of protein in each sample, the membranes were "stripped off", reprobed with actin, developed with horseradishperoxidase-conjugated secondary antibody, and visualized by enhanced chemiluminescence.

\section{Preparation of nuclear extracts and electrophoretic mobility shift assay (EMSA)}

Nuclear protein from ileum tissue was extracted using our previously described method ${ }^{[32,33]}$. Briefly, frozen tissues were weighed, transferred to Corex tubes and homogenized in four volumes $(\mathrm{w} / \mathrm{v}$ ) of PBS containing $2 \mathrm{mmol} / \mathrm{L}$ phenylmethylsulfonyl fluoride (PMSF). The homogenate was centrifuged at $3000 \times g$ for $10 \mathrm{~min}$, and the pellet was then resuspended in $2 \mathrm{~mL}$ buffer A $[0.3 \mathrm{~mol} / \mathrm{L}$ sucrose, $5 \mathrm{mmol} / \mathrm{L}$ dithiothreitol (DTT), $5 \mathrm{mmol} / \mathrm{L}$ $\mathrm{MgCl}_{2} 10 \mathrm{mmol} / \mathrm{L}$ Tris/HCl, $0.1 \%$ Triton X-405], and further homogenized using a Dounce homogenizer. After filtration through a $100-\mu \mathrm{m}$ nylon mesh, the suspension was centrifuged at $1000 \times g$ for $5 \mathrm{~min}$ at $4^{\circ} \mathrm{C}$. The pellet (nuclei) was washed in buffer A (without $0.1 \%$ Triton $\mathrm{X}-405)$ and centrifuged $\left(1000 \times g\right.$ for $5 \mathrm{~min}$ at $\left.4^{\circ} \mathrm{C}\right)$, and then the nuclei were extracted on ice for $30 \mathrm{~min}$ in $60 \mu \mathrm{L}$ buffer B containing $20 \mathrm{mmol} / \mathrm{L}$ HEPES, $0.75 \mathrm{mmol} / \mathrm{L}$ spermidine, $0.15 \mathrm{mmol} / \mathrm{L}$ spermine, $0.2 \mathrm{mmol} / \mathrm{L}$ EDTA, $2 \mathrm{mmol} / \mathrm{L}$ ethylene glycol-bis (b-aminoethyl ether)-N, N, N', N'-tetraacetic acid, $2 \mathrm{mmol} / \mathrm{L}$ DT'T, 20\% glycerol, and $1 \mathrm{mmol} / \mathrm{L}$ PMSF $\left(4^{\circ} \mathrm{C}\right)$ in the presence of $0.4 \mathrm{~mol} / \mathrm{L}$ $\mathrm{NaCl}$. Finally, the samples were centrifuged for $10 \mathrm{~min}$ at $21000 \times g\left(4^{\circ} \mathrm{C}\right)$, and the supernatants were collected and stored at $-80^{\circ} \mathrm{C}$ as the nuclear protein fraction.

For EMSA, $5 \mu \mathrm{g}$ total nuclear proteins was incubated with 1.0 pmol double-stranded $\gamma\left[^{32} \mathrm{P}\right]$ ATP end-labeled oligonucleotides containing consensus binding sequences for $\mathrm{NF}_{-} \kappa \mathrm{B}$ (sense strand 5'-AGGGACTTTCCGCTG GGGACTTTCC-3') in a binding buffer $(10 \mathrm{mmol} / \mathrm{L}$ HEPES, pH 7.9, $80 \mathrm{mmol} / \mathrm{L} \mathrm{NaCl}, 3 \mathrm{mmol} / \mathrm{L} \mathrm{MgCl}_{2}$, $0.1 \mathrm{mmol} / \mathrm{L}$ EDTA, $1 \mathrm{mmol} / \mathrm{L}$ DTT, $1 \mathrm{mmol} / \mathrm{L}$ PMSF, and $10 \%$ glycerol), as described previously ${ }^{[34]}$. Samples were incubated for $30 \mathrm{~min}$ at room temperature and then run through a $4 \%$ non-denaturing polyacrylamide gel $(0.5 \times$ TBE buffer) at $280 \mathrm{~V}$ for $1 \mathrm{~h}$. The gel was dried and then exposed to X-ray film (Kodak) for 4-6 h in cassettes at $-80^{\circ} \mathrm{C}$. Signal detection and quantification were performed by computer-assisted densitometry.

\section{Statistical analysis}

All the values are presented as mean \pm SE. Statistical analysis was performed by ANOVA and Student's $t$ test for the comparisons. $P<0.05$ was considered to be statistically significant.

\section{RESULTS}

\section{Histology}

Histological analysis showed that the ileum from sham mice had the normal architecture of the intestinal epithelium and wall, while thermal injury induced severe edema and sloughing of the villous tips, as well as infiltration of inflammatory cells into the mucosa (Figure 1). Semi-quantitative analysis of histological samples of ileum and jejunum showed that granulocyte infiltration in the burned mice was significantly increased compared to that in the sham group. Administration of CORM-2 $(8 \mathrm{mg} / \mathrm{kg}$, i.v.), significantly decreased granulocyte infiltration. However, CORM-2 did not improve the hydropic degeneration induced by thermal injury in either the ileum or jejunum (Table 2).

\section{Effect of CORM-2 on MPO activity in small intestine of thermally injured mice}

To determine whether the burn-induced increase in polymorphonuclear neutrophil (PMN) accumulation in the small intestine was effectively prevented by CORM-2, 


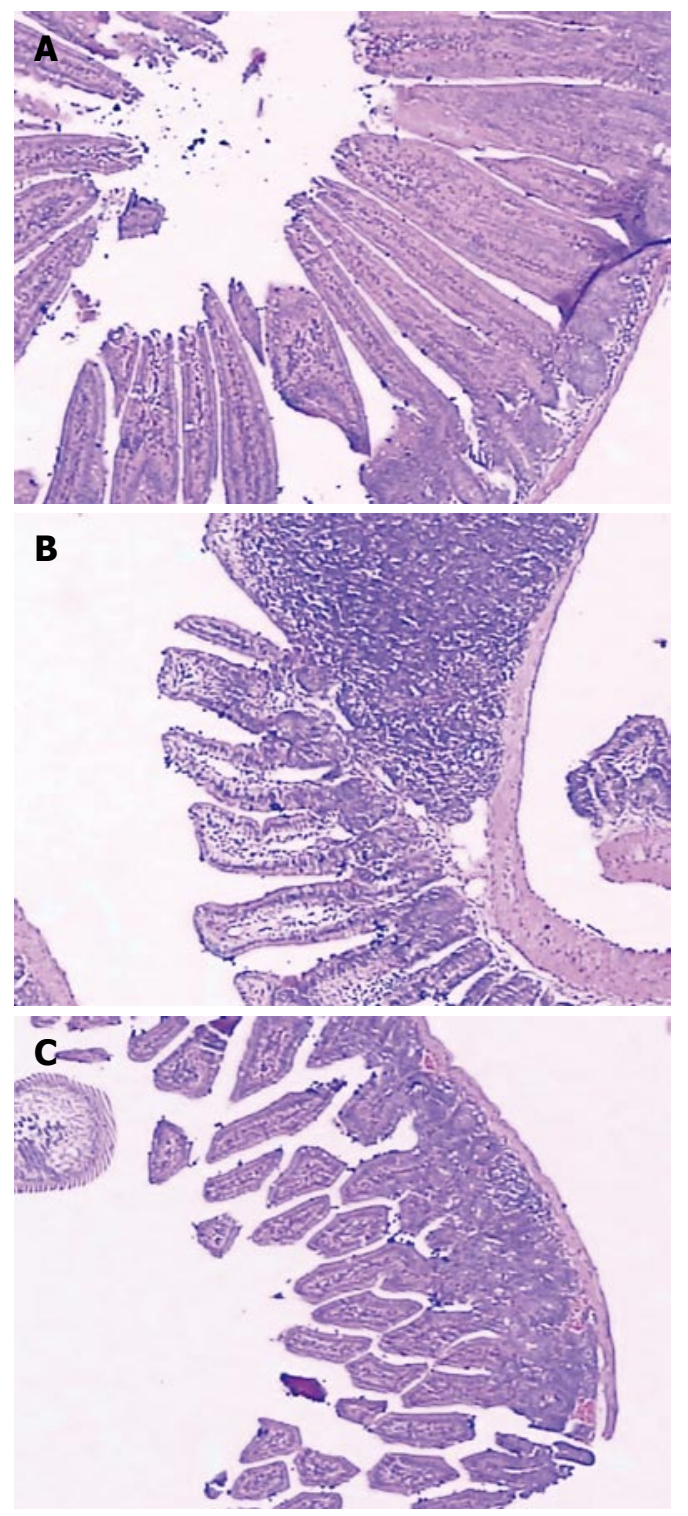

Figure 1 Effects of CORM-2 on small intestine injury in thermally injured mice. Mice were injected i.v. with CORM-2 $(8 \mathrm{mg} / \mathrm{kg})$ immediately after thermal injury. Mice in the DMSO group received a $160-\mu \mathrm{L}$ bolus injection of $0.5 \%$ DMSO/ saline. Mid-ileum sections from sham-treated mice had normal architecture of the intestinal epithelium and wall (A); Mid-ileum sections from thermally injured mice showed inflammatory cell infiltration through the wall, concentrated below the epithelial layer, edema of the distal portion of the villi, and necrosis of the epithelium at the villous tips (B); lleum section from burned mice treated with CORM-2 (C) showed a significant decrease in granulocyte infiltration, while no marked improvement of hydropic degeneration. The figure is representative of at least three experiments performed on different days.

the activity of MPO, an enzyme in azurophilic granules of neutrophils, was assessed. Extracts of the ileum samples were examined for content of MPO $24 \mathrm{~h}$ after thermal injury. The mean MPO levels are shown in Figure 2. MPO activity in organs obtained from burned mice was markedly increased compared to that in the sham group $(P<0.01)$, while it was significantly decreased by treatment with CORM-2 $(P<0.05)$.

\section{Effect of CORM-2 on expression of ICAM-1 in the small intestine of thermally injured mice}

At $24 \mathrm{~h}$ after a $15 \%$ TBSA full-thickness thermal injury,

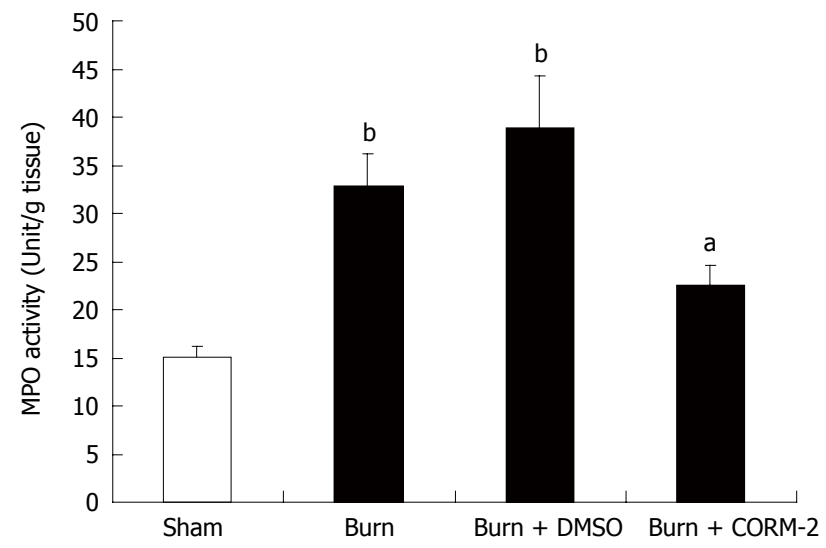

Figure 2 Effects of CORM-2 on MPO activity in the small intestine of thermally injured mice. Mice were challenged with thermal injury and treated with CORM-2 as described in Figure 1. MPO activity in the mid-ileum was assessed $24 \mathrm{~h}$ following thermal injury. Results are mean $\pm \mathrm{SE},{ }^{b} P<0.01$ vs sham mice. ${ }^{\mathrm{a}} P<0.05$ vs burned mice.
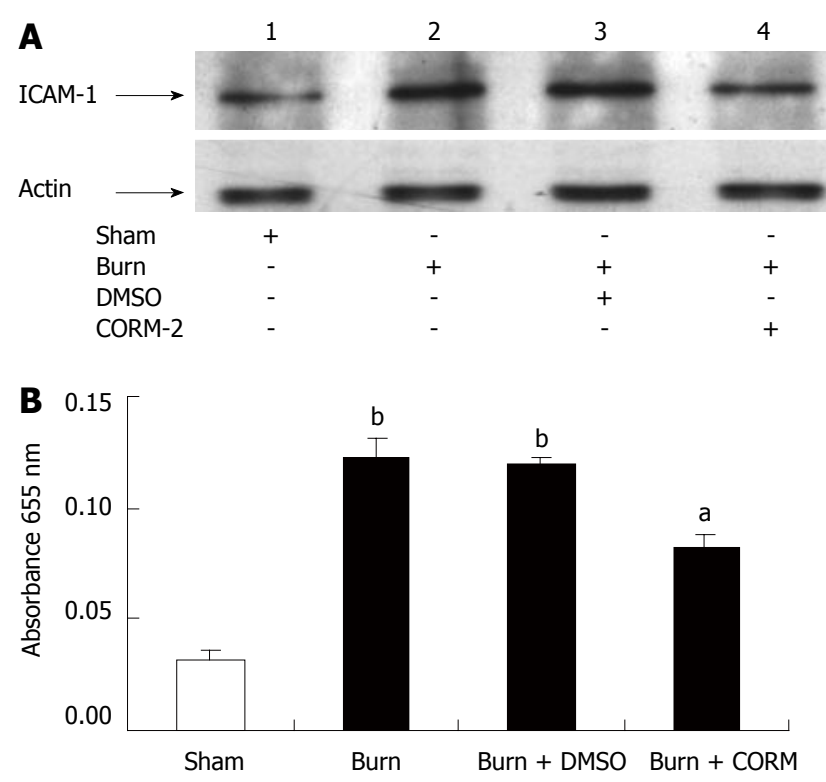

Figure 3 Effects of CORM-2 on protein expression of ICAM-1 in the ileum tissue of thermally injured mice. Mice were challenged with thermal injury and treated with CORM-2 as described in Figure 1. Protein expression of ICAM-1 was analyzed by Western blotting (A) and ELISA (B) $24 \mathrm{~h}$ after thermal injury. A representative experiment is shown in $A .{ }^{b} P<0.01$ vs sham-treated; ${ }^{a} P<0.05$ vs burned mice.

the expression of ICAM-1 in the ileum was significantly increased compared to that in the sham-treated animals. Administration of CORM-2 (8 mg/kg, i.v.) significantly decreased expression of ICAM-1 (Figure 3).

\section{Effect of CORM-2 on expression of HO-1 in the small intestine of thermally injured mice}

At $24 \mathrm{~h}$ after 15\% TBSA full-thickness thermal injury, the expression of HO-1 in the small intestine significantly increased compared to that in the sham-treated animals. In vivo administration of CORM-2 $(8 \mathrm{mg} / \mathrm{kg}$, i.v.), expression of HO-1 in the ileum tissue of burn mice was more significantly increased compared to burn group (Figure 4). 


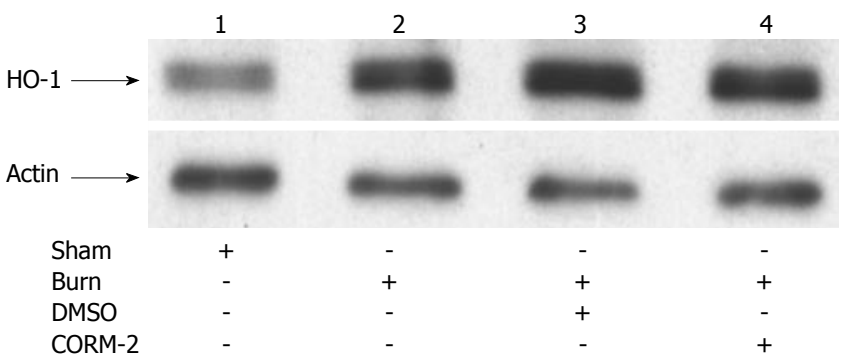

Figure 4 Effects of CORM-2 on protein expression of HO- 1 in the ileum tissue of thermally injured mice. Mice were challenged with thermal injury and treated with CORM-2 as described in Figure 1. Protein expression of HO-1 was performed by Western blotting $24 \mathrm{~h}$ after thermal injury. A representative experiment showed that HO-1 was significantly up-regulated by thermal injury (lane 2). Expression of HO-1 in the small intestine of thermally injured mice treated with CORM-2 was more significantly increased compared to burned mice without CORM-2 (lane 4).

\section{Effect of CORM-2 on activity of NF- $\kappa B$ in the small intestine of thermally injured mice}

Binding of nuclear protein to the radiolabeled consensus binding sequences of NF- $\kappa \mathrm{B}$ was assessed by EMSA. At $24 \mathrm{~h}$ after $15 \%$ TBSA full-thickness thermal injury, NF$\kappa \mathrm{B}$ activation in the ileum was markedly increased, and this was markedly inhibited by administration of CORM-2 (8 $\mathrm{mg} / \mathrm{kg}$ i.v.) (Figure 5).

\section{DISCUSSION}

Major burns alter immune function, which produces an imbalance between pro- and anti-inflammatory cytokine synthesis, and increases susceptibility to postburn infection and sepsis ${ }^{[35-37]}$. Also, severe burns cause damage to multiple organs distant from the original burn wound, leading to MOF, a serious clinical problem. The intestine is one of the most sensitive tissues to ischemia and reperfusion induced by thermal injury. PMNs may play an important role in ischemic injury, and reperfusion of intestine is associated with accumulation of PMNs in the intestinal tissue. It has been suggested that tissue accumulation of PMNs is a key event that determines the severity of ischemia-reperfusion injury ${ }^{[8]}$.

We report here that CORM-released CO exerts a protective effect against the pathological changes caused by thermal injury of the small intestine. Importantly, this exogenous $\mathrm{CO}$ showed effective inhibition of activation of NF- $\kappa \mathrm{B}$ and expression of ICAM-1. Thus, we propose that CORM-2 contributes to the attenuation of leukocyte infiltration to the intestinal tissue after burn challenge. What is, then, the mechanism by which attenuation of PMN infiltration to the intestine is caused by thermal injury?

Many experimental studies have highlighted the specific and independent role of exogenous CO (i.e. $\mathrm{CO}$ inhalation) in the modulation of inflammation ${ }^{[38,39]}$. Recently some new metal carbonyl-based compounds (CORMs) that have the ability to release $\mathrm{CO}$ in biological systems have been identified and synthesized. The vasoactive, antihypertensive and anti-rejection effects of CORMs have been demonstrated to be due to the CO liberated by the compounds. CORM-2, a DMSO-soluble CORM, also has exhibited anti-inflammatory actions in an
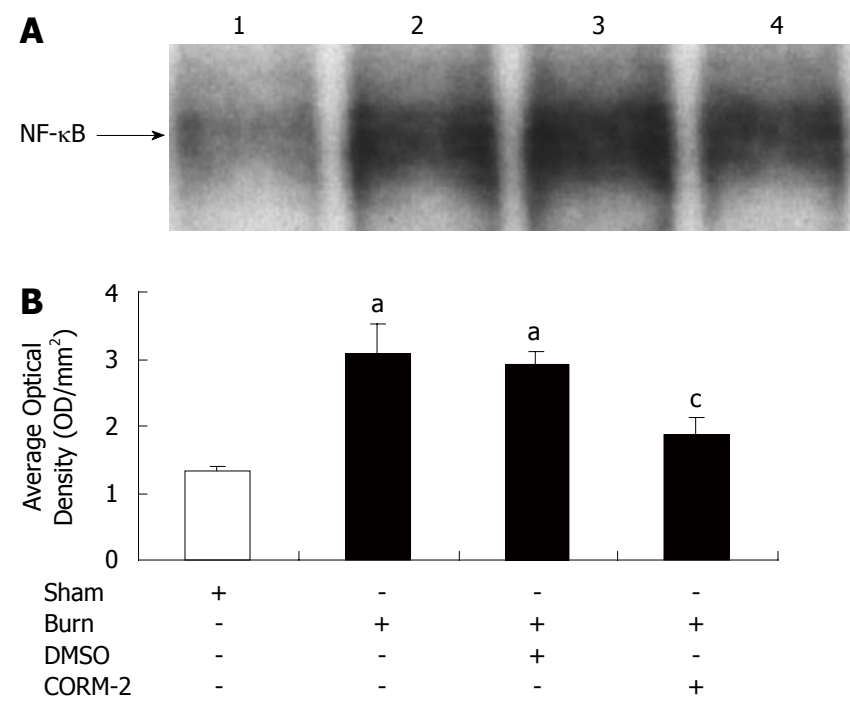

Figure 5 Effects of CORM-2 on NF- $\mathrm{KB}$ activation in the ileum tissue of thermally injured mice. Mice were challenged with thermal injury and treated with CORM-2 as described in Figure 1. Measurement of NF- $\kappa B$ activity was performed by EMSA with ${ }^{32} \mathrm{P}$-labeled $\mathrm{NF}-\kappa \mathrm{B}$ probe and $5 \mu \mathrm{g}$ nuclear extract from the ileum of sham, burn, burn + DMSO and burn+CORM-2 mice at $24 \mathrm{~h}$ after thermal injury. NF- $\mathrm{KB}$ activation in the ileum of thermally injured mice was markedly increased (lane 2), and this activity was inhibited by CORM-2 (lane 4). A representative experiment is shown in $\mathbf{A}$, and quantitative results (average optical density) of three experiments are shown in B. ${ }^{a} P<0.05$ vs sham-treated; ${ }^{c} P<0.05$ vs burned.

in vitro model of LPS-stimulated murine macrophages ${ }^{[40]}$.

MPO is an enzyme that is found predominantly in the azurophilic granules of PMNs. Tissue MPO activity is frequently utilized to estimate tissue PMN accumulation in inflamed tissues, and correlates significantly with the number of PMNs determined histochemically in tissues $^{[41]}$. In the present study, we found that intestinal MPO activity was markedly elevated after thermal injury, and administration of CORM-2 led to significant downregulation of MPO activity. This indicates that CORM-2 effectively prevents PMN chemotaxis and infiltration in the small intestine after thermal injury, which consequently decreases the production of oxidants and reduces tissue oxidative injury, which contributes to MODS. In parallel, histological analysis in this study indicated that mid-ileum sections from thermally injured mice showed inflammatory cell infiltration through the wall, concentrated below the epithelial layer, edema of the distal portion of the villi, and necrosis of the epithelium at the villous tips. On the contrary, ileum sections from mice treated with CORM-2 showed a significant decrease in leukocyte infiltration.

PMN-endothelial cell interactions are supposed to play a central role in the pathogenesis of intestinal barrier failure following thermal injury and ischemiareperfusion ${ }^{[42]}$. The presence of ICAM-1, which mediates leukocyte adhesion, correlates with infiltration of leukocytes into inflammatory lesions ${ }^{[43,44]}$. It seems to be the initial marker of inflammatory reactions and is involved in the acute inflammatory reaction following burns $^{[45]}$. ICAM-1 activates leukocytes and endothelial cells, which in turn, prompt the release of various inflammatory mediators. This may result in SIRS, acute respiratory distress syndrome, and MODS, which may develop further into progressive MOF and death ${ }^{[46-48]}$. The present 
results showed that at $24 \mathrm{~h}$ post-burn, the expression of ICAM-1 in intestinal tissue was markedly up-regulated. CORM-2 was able to inhibit the up-regulation of ICAM-1 induced by thermal injury. Our findings strongly indicate that CORM-2 appears to inhibit leukocyte activation and adhesion, and consequently, might effectively decrease the inflammatory response in the small intestine induced by burns.

$\mathrm{HO}$ is a rate-limiting enzyme that is responsible for the catabolism of heme into bilirubin, free iron, and CO. Three HO isoforms have been identified: HO-2 and HO-3 isoforms are believed to be constitutive and physiologically expressed, whereas HO-1 isoform is a stress-responsive protein that is induced by various stimuli. The adaptive response of HO-1 to various stimuli suggests that it may play an important role in protection against the inflammatory response and oxidative injury ${ }^{[49]}$. Other studies have shown that up-regulation of endogenous HO-1 ameliorates inflammatory responses and/or tissue damage ${ }^{[50]}$. In this study, we found that HO-1 was significantly up-regulated by thermal injury. Interestingly, the expression of HO-1 in the small intestine of thermally injured mice treated with CORM-2 was more significantly increased compared to burned mice without CORM-2 (Figure 4). This result indicates that not only major burn injury might significantly induce the expression of $\mathrm{HO}-1$, but also the increase in HO-1 expression can be further enhanced by the administration of CORM-2. Through the by-product (CO and/or biliverdin), the potent cytoprotective and anti-inflammatory functions were ultimately led to exert.

$\mathrm{NF}-\kappa \mathrm{B}$ family members control transcriptional activity of various promoters of proinflammatory cytokines, cellsurface receptors, transcription factors, and adhesion molecules that are involved in intestinal inflammation ${ }^{[51,52]}$. Stimuli like oxidative stress, cytokines (interleukin-1, interleukin-6, tumor necrosis factor- $\alpha$ ), bacteria and viruses can release $\mathrm{NF}-\kappa \mathrm{B}$ from its inactive cytoplasmic form to the nucleus ${ }^{[33,54]}$. Thermal injury has been known to induce hepatic NF- $\mathrm{B}$ expression associated with hepatic cell apoptosis and proliferation ${ }^{[55]}$, but its effect on NF$\kappa \mathrm{B}$ activation in the intestine has never been clarified. Previously, using a thermal injury model in mice, we have shown that CORM-2 plays a pivotal role in inhibition of $N F-\kappa \mathrm{B}$ activity in the liver, which subsequently decreases hepatocellular secretion of inflammatory cytokines and burn-related hepatic dysfunction. In this study, $\mathrm{NF}_{-\kappa \mathrm{B}}$ activity in mid-ileum was elevated by thermal injury, while it was markedly inhibited by administration of CORM-2. These results show that CORM-2 plays, at least partly, an important role in inhibition of $\mathrm{NF}-\kappa \mathrm{B}$ activity in the small intestine. Therefore, the role of $\mathrm{NF}-\kappa \mathrm{B}$ activation and the regulation of CORM-2 in thermal-injury-induced intestinal damage requires further study.

In conclusion, the present study serves to clarify the role of CORM-2, one of the novel CORMs, on the mechanisms of anti-inflammation and cytoprotection. Application of CORM-2 to thermally injured mice attenuated PMN accumulation, and prevented activation of $\mathrm{NF}_{-} \kappa \mathrm{B}$ in the small intestine. This was accompanied by a decrease in expression of ICAM-1, and an increase in expression of HO-1. Taken together, these findings indicate that CORM-released CO modulates gut inflammation in burned mice by interfering with NF$\kappa \mathrm{B}$ activation, and protein expression of ICAM-1 and HO-1, and therefore suppresses the pro-adhesive phenotype of endothelial cells. Further studies are now required to understand the detailed mechanisms of the anti-inflammatory effects mediated by CORMs, and to contribute to the development of a therapeutic approach to protect against gut damage during severe burn injury.

\section{COMMENTS}

\section{Background}

SIRS and MOF still continue to be leading causes of morbidity and mortality in severe burn patients. The intestine is considered to be the critical organ in the development of organ dysfunction in trauma, burn and intensive care unit patients. Thermal injury is accompanied by complex events that exert deleterious effects on various organs, such as the small intestine, distant from the original burn wound. Following thermal injury, the small intestine is subjected to ischemia, and consequently, especially during burn resuscitation, reperfusion injury occurs. Intestinal ischemia-reperfusion results in organ injury through both tissue hypoxia and reperfusion phenomena mediated by neutrophils. A variety of cytokines are released into the microcirculation by neutrophils, endothelial cells and monocytes during hypoxia and reperfusion. Although the pathophysiological basis of organ damage remains unclear, there is increasing evidence that leukocyte infiltration into intestinal tissue plays an important role in bacterial or endotoxin translocation, and development of SIRS after thermal injury.

\section{Research frontiers}

Major burns alter immune function, which produces an imbalance between proand anti-inflammatory cytokine synthesis, and increases susceptibility to post-burn infection and sepsis. Also, severe burns cause damage to several organs distant from the original burn wound, which leads to MOF, a serious clinical problem. The intestine is one of the most sensitive tissues to ischemia and reperfusion induced by thermal injury. PMNs may play an important role in ischemic injury, and reperfusion of the intestine is associated with accumulation of PMNs in the intestinal tissue. It has been suggested that tissue accumulation of PMNs is a key event that determines the severity of ischemia-reperfusion injury.

\section{Innovations and breakthroughs}

Our study is believed to be the first to observe that CORM-released CO attenuates leukocyte infiltration in the small intestine of thermally injured mice, and the possible mechanisms involved.

\section{Applications}

Our research observed that CORM-released $\mathrm{CO}$ attenuates leukocyte infiltration in the small intestine of thermally injured mice by interfering with $\mathrm{NF}-\kappa \mathrm{B}$ activation and protein expression of ICAM-1, and therefore suppresses the pro-adhesive phenotype of endothelial cells. This may have a significant clinical impact in the future.

\section{Terminology}

CORMs: transitional metal carbonyls that have been identified as potential COreleasing molecules with the potential to facilitate the pharmaceutical use of $\mathrm{CO}$ by delivering it to tissues and organs.

\section{Peer review}

This is a well-written paper that suggests the benefit of CORMs after burn injury. Although the mechanism remains to be determined, I think it may be suitable for publication in WJG. It will be nice to detail other experiments using other doses of CORMs.

\section{REFERENCES}

1 Sittig K, Deitch EA. Effect of bacteremia on mortality after 
thermal injury. Arch Surg 1988; 123: 1367-1370

2 Housinger TA, Brinkerhoff $\mathrm{C}$, Warden GD. The relationship between platelet count, sepsis, and survival in pediatric burn patients. Arch Surg 1993; 128: 65-66; discussion 66-67

3 Moore EE. Mesenteric lymph: the critical bridge between dysfunctional gut and multiple organ failure. Shock 1998; 10: 415-416

4 Ward PA, Till GO. Pathophysiologic events related to thermal injury of skin. J Trauma 1990; 30: S75-S79

5 Li L, Zhang YM, Qiao WL, Wang L, Zhang JF. Effects of hypothalamic paraventricular nuclei on apoptosis and proliferation of gastric mucosal cells induced by ischemia/ reperfusion in rats. World J Gastroenterol 2007; 13: 874-881

6 Liu KX, Wu WK, He W, Liu CL. Ginkgo biloba extract (EGb 761) attenuates lung injury induced by intestinal ischemia/ reperfusion in rats: roles of oxidative stress and nitric oxide. World J Gastroenterol 2007; 13: 299-305

7 Wyble CW, Desai TR, Clark ET, Hynes KL, Gewertz BL. Physiologic concentrations of TNFalpha and IL-1beta released from reperfused human intestine upregulate E-selectin and ICAM-1. J Surg Res 1996; 63: 333-338

8 Kuwabara Y, Kato T, Sato A, Fujii Y. Prolonged effect of leukocytosis on reperfusion injury of rat intestine: real-time ATP change studied using (31)P MRS. J Surg Res 2000; 89: 38-42

9 Sener G, Sehirli AO, Satiroğlu H, Keyer-Uysal M, C Yeğen B. Melatonin improves oxidative organ damage in a rat model of thermal injury. Burns 2002; 28: 419-425

10 Horton JW. Free radicals and lipid peroxidation mediated injury in burn trauma: the role of antioxidant therapy. Toxicology 2003; 189: 75-88

11 Sun Z, Wang X, Lasson A, Böjesson A, Annborn M, Andersson R. Effects of inhibition of PAF, ICAM-1 and PECAM-1 on gut barrier failure caused by intestinal ischemia and reperfusion. Scand J Gastroenterol 2001; 36: 55-65

12 Ghandour S, Cetinel S, Kurtel H. Endothelin-3 induced mesenteric vasoconstriction and PMN infiltration in the rat small intestine: role of endothelin receptors. Regul Pept 2004; 119: $125-131$

13 Hayashi S, Takamiya R, Yamaguchi T, Matsumoto K, Tojo SJ, Tamatani T, Kitajima M, Makino N, Ishimura Y, Suematsu M. Induction of heme oxygenase-1 suppresses venular leukocyte adhesion elicited by oxidative stress: role of bilirubin generated by the enzyme. Circ Res 1999; 85: 663-671

14 Lee TS, Chau LY. Heme oxygenase- 1 mediates the antiinflammatory effect of interleukin-10 in mice. Nat Med 2002; 8: 240-246

15 Otterbein LE, Soares MP, Yamashita K, Bach FH. Heme oxygenase-1: unleashing the protective properties of heme. Trends Immunol 2003; 24: 449-455

16 Motterlini R, Mann BE, Johnson TR, Clark JE, Foresti R, Green CJ. Bioactivity and pharmacological actions of carbon monoxide-releasing molecules. Curr Pharm Des 2003; 9: 2525-2539

17 Motterlini R, Clark JE, Foresti R, Sarathchandra P, Mann $\mathrm{BE}$, Green CJ. Carbon monoxide-releasing molecules: characterization of biochemical and vascular activities. Circ Res 2002; 90: E17-E24

18 Motterlini R, Sawle P, Hammad J, Bains S, Alberto R, Foresti R, Green CJ. CORM-A1: a new pharmacologically active carbon monoxide-releasing molecule. FASEB J 2005; 19: 284-286

19 Johnson TR, Mann BE, Clark JE, Foresti R, Green CJ, Motterlini R. Metal carbonyls: a new class of pharmaceuticals? Angew Chem Int Ed Engl 2003; 42: 3722-3729

20 Foresti R, Hammad J, Clark JE, Johnson TR, Mann BE, Friebe A, Green CJ, Motterlini R. Vasoactive properties of CORM-3, a novel water-soluble carbon monoxide-releasing molecule. $\mathrm{Br} \mathrm{J}$ Pharmacol 2004; 142: 453-460

21 Clark JE, Naughton P, Shurey S, Green CJ, Johnson TR, Mann BE, Foresti R, Motterlini R. Cardioprotective actions by a water-soluble carbon monoxide-releasing molecule. Circ Res 2003; 93: e2-e8

22 Guo Y, Stein AB, Wu WJ, Tan W, Zhu X, Li QH, Dawn B,
Motterlini R, Bolli R. Administration of a CO-releasing molecule at the time of reperfusion reduces infarct size in vivo. Am J Physiol Heart Circ Physiol 2004; 286: H1649-H1653

23 Sun BW, Chen ZY, Chen X, Liu C. Attenuation of leukocytes sequestration by carbon monoxide-releasing molecules: liberated carbon monoxide in the liver of thermally injured mice. J Burn Care Res 2007; 28: 173-181

24 Sun B, Sun H, Liu C, Shen J, Chen Z, Chen X. Role of COreleasing molecules liberated $\mathrm{CO}$ in attenuating leukocytes sequestration and inflammatory responses in the lung of thermally injured mice. J Surg Res 2007; 139: 128-135

25 Faunce DE, Gregory MS, Kovacs EJ. Effects of acute ethanol exposure on cellular immune responses in a murine model of thermal injury. J Leukoc Biol 1997; 62: 733-740

26 Gamelli RL, He LK, Liu H. Macrophage suppression of granulocyte and macrophage growth following burn wound infection. J Trauma 1994; 37: 888-892

27 Stengle J, Meyers R, Pyle J, Dries DJ. Neutrophil recruitment after remote scald injury. J Burn Care Rehabil 1996; 17: 14-18

28 Faunce DE, Llanas JN, Patel PJ, Gregory MS, Duffner LA, Kovacs EJ. Neutrophil chemokine production in the skin following scald injury. Burns 1999; 25: 403-410

29 Rana SN, Li X, Chaudry IH, Bland KI, Choudhry MA. Inhibition of IL-18 reduces myeloperoxidase activity and prevents edema in intestine following alcohol and burn injury. J Leukoc Biol 2005; 77: 719-728

30 Hillegass LM, Griswold DE, Brickson B, Albrightson-Winslow C. Assessment of myeloperoxidase activity in whole rat kidney. J Pharmacol Methods 1990; 24: 285-295

31 Mullane KM, Kraemer R, Smith B. Myeloperoxidase activity as a quantitative assessment of neutrophil infiltration into ischemic myocardium. J Pharmacol Methods 1985; 14: 157-167

32 Lush CW, Cepinskas G, Kvietys PR. Regulation of intestinal nuclear factor-kappaB activity and E-selectin expression during sepsis: a role for peroxynitrite. Gastroenterology 2003, 124: $118-128$

33 Cepinskas G, Lush CW, Kvietys PR. Anoxia/reoxygenationinduced tolerance with respect to polymorphonuclear leukocyte adhesion to cultured endothelial cells. A nuclear factor-kappaB-mediated phenomenon. Circ Res 1999; 84: 103-112

34 Bielinska A, Shivdasani RA, Zhang LQ, Nabel GJ. Regulation of gene expression with double-stranded phosphorothioate oligonucleotides. Science 1990; 250: 997-1000

35 Ayala A, Chung CS, Grutkoski PS, Song GY. Mechanisms of immune resolution. Crit Care Med 2003; 31: S558-S571

36 Mannick JA, Rodrick ML, Lederer JA. The immunologic response to injury. J Am Coll Surg 2001; 193: 237-244

37 White J, Thomas J, Maass DL, Horton JW. Cardiac effects of burn injury complicated by aspiration pneumonia-induced sepsis. Am J Physiol Heart Circ Physiol 2003; 285: H47-H58

38 Otterbein LE, Bach FH, Alam J, Soares M, Tao Lu H, Wysk M, Davis RJ, Flavell RA, Choi AM. Carbon monoxide has antiinflammatory effects involving the mitogen-activated protein kinase pathway. Nat Med 2000; 6: 422-428

39 Nakao A, Moore BA, Murase N, Liu F, Zuckerbraun BS, Bach FH, Choi AM, Nalesnik MA, Otterbein LE, Bauer AJ. Immunomodulatory effects of inhaled carbon monoxide on rat syngeneic small bowel graft motility. Gut 2003; 52: 1278-1285

40 Sawle P, Foresti R, Mann BE, Johnson TR, Green CJ, Motterlini $\mathrm{R}$. Carbon monoxide-releasing molecules (CO-RMs) attenuate the inflammatory response elicited by lipopolysaccharide in RAW264.7 murine macrophages. Br J Pharmacol 2005; 145: 800-810

41 Bradley PP, Priebat DA, Christensen RD, Rothstein G. Measurement of cutaneous inflammation: estimation of neutrophil content with an enzyme marker. J Invest Dermatol 1982; 78: 206-209

42 Oktar BK, Coşkun T, Bozkurt A, Yegen BC, Yüksel M, Haklar G, Bilsel S, Aksungar FB, Cetinel U, Granger DN, Kurtel H. Endothelin-1-induced PMN infiltration and mucosal dysfunction in the rat small intestine. Am J Physiol Gastrointest Liver Physiol 2000; 279: G483-G491 
43 Defazio G, Nico B, Trojano M, Ribatti D, Giorelli M, Ricchiuti F, Martino D, Roncali L, Livrea P. Inhibition of protein kinase $C$ counteracts TNFalpha-induced intercellular adhesion molecule 1 expression and fluid phase endocytosis on brain microvascular endothelial cells. Brain Res 2000; 863: 245-248

44 Rahman A, True AL, Anwar KN, Ye RD, Voyno-Yasenetskaya TA, Malik AB. Galpha(q) and Gbetagamma regulate PAR-1 signaling of thrombin-induced NF-kappaB activation and ICAM-1 transcription in endothelial cells. Circ Res 2002; 91: 398-405

45 Mileski WJ, Burkhart D, Hunt JL, Kagan RJ, Saffle JR, Herndon DN, Heimbach DM, Luterman A, Yurt RW, Goodwin CW, Hansborough J. Clinical effects of inhibiting leukocyte adhesion with monoclonal antibody to intercellular adhesion molecule-1 (enlimomab) in the treatment of partialthickness burn injury. J Trauma 2003; 54: 950-958

46 Sparkes BG, Gyorkos JW, Gorczynski RM, Brock AJ. Comparison of endotoxins and cutaneous burn toxin as immunosuppressants. Burns 1990; 16: 123-127

47 Deveci M, Eski M, Sengezer M, Kisa U. Effects of cerium nitrate bathing and prompt burn wound excision on IL-6 and TNF-alpha levels in burned rats. Burns 2000; 26: 41-45

48 Cuschieri J, Gourlay D, Garcia I, Jelacic S, Maier RV. Modulation of endotoxin-induced endothelial activity by microtubule depolymerization. J Trauma 2003; 54: 104-112. discussion 112-113

49 Willis D, Moore AR, Frederick R, Willoughby DA. Heme oxygenase: a novel target for the modulation of the inflammatory response. Nat Med 1996; 2: 87-90

50 Attuwaybi BO, Kozar RA, Moore-Olufemi SD, Sato N, Hassoun HT, Weisbrodt NW, Moore FA. Heme oxygenase-1 induction by hemin protects against gut ischemia/reperfusion injury. J Surg Res 2004; 118: 53-57

51 Hierholzer C, Kalff JC, Billiar TR, Bauer AJ, Tweardy DJ, Harbrecht BG. Induced nitric oxide promotes intestinal inflammation following hemorrhagic shock. Am J Physiol Gastrointest Liver Physiol 2004; 286: G225-G233

52 Hassoun HT, Fischer UM, Attuwaybi BO, Moore FA, Safi HJ, Allen SJ, Cox CS Jr. Regional hypothermia reduces mucosal NF-kappaB and PMN priming via gut lymph during canine mesenteric ischemia/reperfusion. J Surg Res 2003; 115: 121-126

53 Yin MJ, Yamamoto Y, Gaynor RB. The anti-inflammatory agents aspirin and salicylate inhibit the activity of I(kappa)B kinase-beta. Nature 1998; 396: 77-80

54 Bellas RE, FitzGerald MJ, Fausto N, Sonenshein GE. Inhibition of NF-kappa B activity induces apoptosis in murine hepatocytes. Am J Pathol 1997; 151: 891-896

55 Wang CY, Mayo MW, Baldwin AS Jr. TNF- and cancer therapy-induced apoptosis: potentiation by inhibition of NFkappaB. Science 1996; 274: 784-787

S- Editor Liu Y L- Editor Kerr C E- Editor Ma WH 